\title{
An Analysis of Competitiveness and Complementarity between China and Guinea Trade under the "The Belt and Road" Initiative
}

\author{
Xiangyu Wei ${ }^{1, a}$, Ze Tian', ${ }^{2, b,}$ \\ ${ }^{1}$ College of Business Administration, Hohai University, Changzhou Jiangsu 213022, China \\ 2 South Institute of Economic Research, Hohai University, Changzhou Jiangsu 213022, China \\ a1005328445@qq.com, btianze21@126.com \\ * Xiangyu Wei
}

Keywords: The Belt and Road, Bilateral trade, Trade competitiveness and complementarity.

\begin{abstract}
With the continuous advancement of the "The Belt and Road" initiative and the continuous development of China-Africa trade cooperation, bilateral trade development between China and Guinea has also ushered in new opportunities. At present, China has become one of the largest trading partners and largest investors of Guinea. By measuring the Export Similarity Index (ESI) , Trade Intensity Index （TII）, Intra-industry Trade Index （G-L Index） and Revealed Comparative Advantage Index ( RCA), this paper analyzes the competitiveness and complementarity of bilateral trade between China and Guinea. The results show that China and Guinea have weaker trade competitiveness but strong complementarities, and huge potential for trade cooperation. It puts forward proposals for improving China and Guinea to jointly discuss and build a sharing mechanism, promote the construction of the "The Belt and Road" infrastructure, and build a China-Guinea economic and trade cooperation industrial park.
\end{abstract}

\section{Introduction}

On February 28, 2015, our country issued the "Vision and Action to Promote the Joint Construction of the Silk Road Economic Belt and the 21st Century Maritime Silk Road", and " The Belt and Road" propose preludes. On May 14-15, 2017, " The Belt and Road" International Cooperation Summit Forum was held in Beijing. As an important country to promote "The Belt and Road" initiative, Africa was also invited to attend the summit. China is becoming one of the most important partners on the road to African development. According to the latest data of the Ministry of Commerce in 2017, China has become Africa's largest trading partner and the third largest source of investment. Guinea, as the first Sub-Saharan African country to establish diplomatic ties with China, has an important position in the construction of China-Africa " The Belt and Road ". In order to further develop the bilateral trade between China and Guinea, expand friendly exchanges and practical cooperation in various fields between the two countries, achieve mutual benefit and win-win results, it is necessary to study on the competitiveness and complementarity of China-Guinea bilateral trade. Through empirical analysis of the competitiveness and complementarity of China's trade with Guinea, it provides a corresponding theoretical basis and policy support for strengthening trade cooperation between the two countries under the "The Belt and Road" strategy.

\section{Current situation of bilateral trade between China and Guinea}

China and Guinea established diplomatic relations on October 4, 1959, and the relations between the two countries have developed smoothly since the establishment of diplomatic ties. Bilateral trade relations and technological cooperation are also developing rapidly. China has built a radio and television center, People's Palace, Jinkang and Butanzhuang hydropower stations, free cinemas, cigarette matches, presidential palaces, and hospitals for Guinea. In September 1960, China and Guinea signed a trade and payment agreement. Since 1985, Chinese companies have entered the 
Guinean labor market. In July 1988, the two countries signed a trade agreement. In January 1997, the two countries signed a fishery cooperation agreement and an agricultural cooperation and development agreement. In November 2005, the two countries signed an agreement to promote and mutually protect investment. In 2012, bilateral trade volume was 764 million U.S. dollars, with a year-on-year increase of $18.5 \%$. Among them, China exported 754 million U.S. dollars and imported 0.1 billion U.S. dollars. China mainly exports transport vehicles and motorcycles, and imports timber, aluminum ore, etc. Since 2013, the total volume of China's import and export trade with Guinea has increased. In 2015, the total bilateral trade between China and Guinea exceeded US \$1.6 billion. During the construction of "The Belt and Road", China has increased its investment in Africa. The Minister of State of Guinea stated that China's investment is a speed increaser for African economic development. When meeting with Guinean President Conte, President Xi Jinping made it clear that it is necessary to strengthen win-win cooperation, promote cooperation in infrastructure construction, mineral development, and agriculture, as well as promoting bilateral trade development.

\section{Analysis of Competitiveness and Complementarity between China and Guinea}

This paper examines the competitiveness and complementarity of bilateral trade between China and Guinea. Select the Export Similarity Index （ESI）, Trade Intensity Index （TII）, Intra-industry Trade Index （G-L Index ） and Revealed Comparative Advantage Index （RCA） to conduct an in-depth analysis of trade between China and Guinea.

\subsection{Competitive Analysis of Trade between China and Guinea}

\subsubsection{Analysis of Export Similarity Index between China and Guinea}

Export Similarity Index is uesd to measure the degree of similarity between any two countries' exports in the common market, in turn reflecting the competitiveness of the export trade between the two countries. The formula is:

$$
E S I_{a b}=\left\{\sum_{i=0}^{n}\left[\left(\frac{x_{a k}^{i} / x_{a k}+x_{b k}^{i} / x_{b k}}{2}\right) \times\left(1-\left|\frac{x_{a k}^{i} / x_{a k}-x_{b k}^{i} / x_{b k}}{x_{a k}^{i} / x_{a k}+x_{b k}^{i} / x_{b k}}\right|\right)\right]\right\} \times 100
$$

Where, $a$ and $b$ refer to country $a$ and country $b$ respectively, and $k$ refers to the common market. $X_{a k}^{i} / X_{a k}$ is the total value of the $i$ product exported from country $a$ to the $k$ market divided by the total of all products exported from country $a$ to market $k \cdot X_{b k}^{i} / X_{b k}$ is the total value of the $i$ product exported from country $b$ to the $k$ market divided by the total of all products exported from country $b$ to market $k$. The range of the $E S I_{a b}$ index is $0-100$. The larger the index, the closer to 100 , indicating that the higher the degree of similarity between the export products of the two countries is, the stronger the competition exists and the more intense the competition is. Conversely, the closer to 0 , the less competitive, the more complementary.

Finding data in the UN COMTRADE database, the common markets found in China and Guinea include the United States, Germany, and India. Use formula (1) to calculate the similarity of exports between China and Guinea in the world market and the three common markets and analyze related trade relations.

Table 1 Export Similarity Index between China and Guinea

\begin{tabular}{c|c|c|c|c}
\hline Year & World Market & USA & Germany & India \\
\hline 2013 & 20.46 & 12.64 & 2.11 & 2.27 \\
\hline 2014 & 17.58 & 12.44 & 3.20 & 1.71 \\
\hline 2015 & 19.80 & 5.11 & 3.29 & 1.66 \\
\hline
\end{tabular}

Note: Guinea-related data were missing from 2009-2012, the same below.

From Table 1, we can find that in the world market and the three common markets of the United States, Germany, and India. Neither China nor Guinea's export similarity index exceeded 21. It shows that several export products are less competitive and have strong complementarity. From the perspective of dynamic changes from 2013 to 2015, the similarity index between China and Guinea has basically declined. It shows that there are more and more trade development opportunities 
between China and Guinea, and the trade complementarity becomes more and more obvious. In the U.S. market, the similarity index between China and Guinea dropped faster in 2015, indicating that China and Guinea have less product export friction and enhanced complementarity in the U.S. market. In the German and Indian markets, the similarity index between China and Guinea's exports is small and dynamic changes are minor. We should continue to play a complementary role in trade and promote the development of bilateral trade.

\subsubsection{Analysis of Trade Intensity Index between China and Guinea}

Trade Intensity Index is a comprehensive indicator used to measure the interdependence of the two countries in terms of trade. The degree of trade integration refers to the proportion of a country's exports to a trading partner country to its total exports divided by the ratio of the total amount of imports by that trading partner country to the total amount of world imports. The greater the value, the closer the two countries are in terms of trade. The formula is:

$$
T I_{a b}=\left(X_{a b} / X_{a}\right) /\left(M_{b} / M_{w}\right)
$$

Where, $a$ and $b$ refer to country $a$ and country $b$ respectively, and $w$ refers to the world market. $X_{a b}$ refers to the total product exported from country $a$ to country $b . X_{a}$ refers to the total exports of country $a . M_{b}$ refers to the total imports of country $b . M_{w}$ refers to the total imports of the world. When $T I I_{a b}<1$, the trade links between the two countries are loose. When $T I I_{a b} \geq 1$, the trade links between the two countries are close. Use formula (2) to measure the trade intensity index between China and Guinea.

Table 2 Trade Intensity Index between China and Guinea

\begin{tabular}{c|c|c}
\hline Year & From China to Guinea & From Guinea to China \\
\hline 2013 & 3.252 & 0.234 \\
\hline 2014 & 3.574 & 0.132 \\
\hline 2015 & 4.395 & 0.177 \\
\hline
\end{tabular}

As can be seen from Table 2, China's trade intensity index for Guinea has been consistently greater than 1, and has continued to grow for three years. It shows that China has closer trade links with Guinea and that trade cooperation has continued to strengthen in recent years. However, judging from Guinea's trade integration with China, the index has been less than 1, indicating that Guinea's trade ties with China are loose. However, the index of trade integration increased from 2014 to 2015, indicating that Guinea's trade cooperation with China began to strengthen. Obviously, there is asymmetry in the degree of trade integration between China and Guinea, and the degree of trade dependence between the two countries is very different. Since 2014, the trade intensity index between China and Guinea has both shown an upward trend and a rapid growth rate. This shows that in the process of "The Belt and Road" development, African countries' reliance on China has been strengthened, and trade cooperation between China and Guinea continues to grow and steadily increases.

\subsection{Complementarity Analysis of Trade between China and Guinea}

\subsubsection{Analysis of Intra-industry Trade Index between China and Guinea}

The intra-industry trade index is an index used to measure the degree of intra-industry trade in an industry. It means that the two countries in the industry have different quality trade relations with each other. The G-L index is a relatively common indicator for the study of intra-industry trade. This article uses the G-L index to analyze the intra-industry trade between China and Guinea. The formula is as follows:

$$
G L_{\tilde{i}}=1-\left|X_{\tilde{i}}-M_{i}\right| /\left(X_{\tilde{i}}+M_{i}\right)
$$

Where, $X_{i}$ is the total export of $i$ products, $M_{i}$ is the total import of $i$ products. The G-L index is in the range $[0,1]$. The situation of the two endpoint values is: When a country has only imported or only exports in a certain industry, it considers that the country has no intra-industry trade at that time, or that its intra-industry trade level takes the lowest value. $X_{i}$ or $M_{i}$ is 0 , the G-L index is 0 . When a country's imports and exports in a certain industry are equal, it is considered that at that time, the level of intra-industry trade in the country is at its maximum. $X_{i}$ is equal to $M_{i}$, the G-L 
index is 1. Therefore, the closer the value of the G-L index is to 0 , the lower the level of intra-industry trade; the closer the value is to 1, the higher the level of intra-industry trade. When $G L_{i}>0.5$, it shows that intra-industry trade accounts for a comparative advantage. When $G L_{i}<0.5$, is shows that inter-industry trade accounts for a comparative advantages. Using formula (3) to measure China's intra-industry trade index with Guinea, as shown in Table 3.

Table 3 G-L Index between China and Guinea

\begin{tabular}{c|c|c|c|c|c|c|c|c|c|c}
\hline Year & SITC0 & SITC1 & SITC2 & SITC3 & SITC4 & SITC5 & SITC6 & SITC7 & SITC8 & SITC9 \\
\hline 2013 & 0.036 & 0 & 0.027 & 0 & 0 & 0.003 & 0 & 0.013 & 0 & 0.432 \\
\hline 2014 & 0.554 & 0 & 0.022 & 0 & 0 & 0 & 0.011 & 0.007 & 0 & 0.013 \\
\hline 2015 & 0.469 & 0 & 0.100 & 0 & 0.011 & 0 & 0.004 & 0.163 & 0.004 & 0.033 \\
\hline
\end{tabular}

The results in Table 3 show that most G-L indexs of China and Guinea are less than 0.5, which shows an inter-industry trade pattern. It can be found that the SITC1, SITC3, SITC4, SITC5 and SITC8 categories of in-industry trade indices are approximately 0. Among other categories, G-L index of SITC0 are 0.554 and 0.469 in 2014 and 2015. The remaining G-L indexes are much less than 0.5 .The overall performance is mainly represented by inter-industry trade, which shows that the complementarity of bilateral trade between China and Guinea is strong and there is room for greater trade development. China and Guinea have different factor endowments, which makes them have comparative advantages in different categories of products and have strong trade complementarity. In 2015, among the export products of Guinea, SITC9 accounted for $82.55 \%$ and SITC2 accounted for $10.11 \%$. Among Chinese exports, SITC5, SITC6 and SITC7 accounted for $21.73 \%, 19.79 \%$ and $42.60 \%$, respectively. Therefore, there is basically no competition between China and Guinea's export products, showing strong complementarity.

\subsubsection{Analysis of Revealed Comparative Advantage Index between China and Guinea}

Revealed Comparative Advantage Index can determine which industries in a country are more competitive, aiming to quantitatively describe the relative export performance of each industry within a country. It is the most convincing indicator to measure the competitiveness of a country's products or industries in the international market, which can be calculated as follows:

$$
R C A=\left(X_{a}^{i} / X_{a}\right) /\left(X_{w}^{i} / X_{w}\right)
$$

Where, $X_{a}^{i}$ represents the $i$ product export volume of country $a, X_{a}$ represents the total export of all products of country $a, X_{w}^{i}$ represents the $i$ product export volume of the world, $X_{W}$ represents the total export of all products over the world. When $R C A<0.8$, explain that the country's export competitiveness of such products is weak. When $0.8 \leq R C A<1.25$, explaining that this type of product in the country has moderate export competitiveness. When $1.25 \leq R C A<2.5$, explaining that the country's products have strong export competitiveness. When $R C A \geq 2.5$, explaining that this kind of product in this country has very strong export competitiveness. The revealed comparative advantage index in China and Guinea are as follows:

Table 4 Revealed Comparative Advantage Index of Chinese exports

\begin{tabular}{c|c|c|c|c|c|c|c|c|c|c}
\hline Year & SITC0 & SITC1 & SITC2 & SITC3 & SITC4 & SITC5 & SITC6 & SITC7 & SITC8 & SITC9 \\
\hline 2013 & 0.100 & 0.025 & 0.286 & 0.077 & 0.012 & 1.985 & 1.635 & 1.402 & 1.168 & 0.000 \\
\hline 2014 & 0.085 & 0.011 & 0.288 & 0.098 & 0.012 & 2.130 & 1.781 & 1.252 & 1.099 & 0.000 \\
\hline 2015 & 0.072 & 0.015 & 0.250 & 0.136 & 0.009 & 2.008 & 1.615 & 1.200 & 1.070 & 0.001 \\
\hline
\end{tabular}

Table 5 Revealed Comparative Advantage Index of Guinean exports

\begin{tabular}{c|c|c|c|c|c|c|c|c|c|c}
\hline Year & SITC0 & SITC1 & SITC2 & SITC3 & SITC4 & SITC5 & SITC6 & SITC7 & SITC8 & SITC9 \\
\hline 2013 & 2.698 & 0.088 & 5.654 & 0.000 & 0.000 & 0.000 & 0.029 & 0.007 & 0.000 & 11.116 \\
\hline 2014 & 1.593 & 0.000 & 4.349 & 0.000 & 0.000 & 0.000 & 0.013 & 0.000 & 0.000 & 15.726 \\
\hline 2015 & 1.134 & 0.000 & 3.018 & 0.000 & 0.000 & 0.000 & 0.030 & 0.000 & 0.000 & 14.696 \\
\hline
\end{tabular}

By measuring the revealed comparative advantage index of China and Guinea in ten categories of products. It is not difficult to find that SITC5, SITC6 and SITC7 are highly competitive in China's export products, among which SITC5 is the most competitive in the world market, and the RCA index is fluctuating around 2. In addition to these three types of products, SITC8 has moderate 
international export competitiveness, While products in other categories have weaker competitiveness. The category of export products in Guinea is SITC9, which has the strongest international competitiveness. Although SITC2 and SITC0 have strong competitiveness, they have been in a downward trend in the past three years, and the remaining products have very weak competitiveness. This shows that Guinea's export products are relatively simple in form thus it needs to need to strengthen international cooperation. Through comparison, it can be found that China's and Guinea's competitive export products are different, there is basically no trade competition, trade complementarity is strong, and bilateral trade has a wide development space.

\section{Conclusions and Suggestions}

By measuring the Export Similarity Index （ESI）, Trade Intensity Index （TII）, Intra-industry Trade Index （G-L Index ) and Revealed Comparative Advantage Index （RCA）, this paper analyzes the competitive and complementarity of bilateral trade between China and Guinea. On the whole, trade between China and Guinea presents complementary features, remains a huge space for trade cooperation, and huge potential for bilateral trade development. Combined with the results of empirical analysis, the following suggestions are made to promote bilateral trade development between China and Guinea:

First, improve the sharing mechanism between the two sides. Take advantage of the historic opportunity of the "The Belt and Road" initiative for non-capacity cooperation and give full play to Guinea's special status and unique geographical advantages in the West African Community. China attaches great importance to its strategic partnership with Guinea, promotes the in-depth development of bilateral relations, strengthens political and economic mutual trust, effectively solves the key and difficult issues of bilateral economic and trade cooperation, promotes Guinea's infrastructure construction, and strengthens cooperation and exchanges. Build a more stable strategic partnership to promote the rapid development of economic and trade relations between China and Guinea.

Second, promote infrastructure construction in Guinea and increase foreign investment. With the launching of the China Government's aid to the non-Wancun-Television satellite TV project in Guinea, the cooperation between China and Africa has reached a new height. While investing in infrastructure construction, we will focus on improving the logistics network, which will in turn drive the development of service trade, and promote the common development of several commodity services and trade.

Third, improve the cooperation between China and Guinea in production capacity and pay attention to the structural transformation of trade. China and Guinea have different competitive advantages for their products, resulting in a new product network. Focus on the horizontal development and vertical integration of the industry chain, attach importance to the extension of the product value chain, improve the complementary advantages of product trade, and then improve the product value chain, promote the transformation and transformation of trade structure.

At last, build a China-Guinea economic and trade cooperation industrial park. The pattern of China-Africa economic cooperation has undergone profound changes. Building a China-Guinea Economic and Trade Cooperation Industrial Park will greatly improve Guinea's economic development conditions. By efficiently using the comparative advantages brought about by the differences between China and Guinea, promote the integration of economic and trade development between China and Guinea. Improve self-sufficiency and related substitution of related products in Guinea, and make China and Guinea trade under sound and sustainable development.

\section{References}

[1] Xiaodong Lu, Ronglin Li. South-South cooperation: is there a foundation in trade[J]. Journal of Chinese Economic and Foreign Trade Studies,2010,3(3). 
[2] Štefan Bojnec, Imre Fertő. Complementarities of trade advantage and trade competitiveness measures[J]. Applied Economics,2012,44(4).

[3] Jinbo Wang, Research on the Trade Potential of the "The Belt and Road" Economic Corridor-An Empirical Analysis Based on Trade Complementarity, Competitiveness and Industrial International Competitiveness[J]. Asia-Pacific Economic.pp. 93-100+175.2017(04).

[4] Zhizhong Liu. The Competitiveness, Complementarity and Development Potential of Sino-Russian Bilateral Trade under the "The Belt and Road" Strategy[J]. Inquiry into Economic Issues. pp. 95-102+115. 2017(07).

[5] Alemayehu Geda,Edris Hussein Seid. The potential for internal trade and regional integration in Africa[J]. Journal of African Trade,2015,2(1-2).

[6] Zitong Huang.A Study on the Competitiveness and Complementarity of the Trade Cooperation between China and Nigeria[J].China Economic and Trade Guide.pp.21-23.2017(17). 